\title{
Aggregations of Arctic deep-sea scavengers at large food falls: temporal distribution, consumption rates and population structure
}

\author{
Katrin Premke $^{1,2, *}$, Michael Klages ${ }^{1}$, Wolf E. Arntz ${ }^{1}$ \\ ${ }^{1}$ Alfred Wegener Institute for Polar and Marine Research, Am Handelshafen 12, 27570 Bremerhaven, Germany \\ ${ }^{2}$ Present address: Department of Ecology and Evolution, Limnology, Husargatan 3, 75123 Uppsala, Sweden
}

\begin{abstract}
Scavenging amphipods were studied at 6 locations in the Fram Strait (Arctic Ocean). At each location a tripod lander equipped with a time-lapse camera, acoustic doppler current profiler and baited traps was deployed at water depths between 1500 and $2600 \mathrm{~m}$. All amphipods, both on photographs and captured, belonged to the superfamily Lysianassoidea or Stegocephaloidea. Differences between the stations occurred in time and number of amphipod maxima, consumption rates, taxonomic composition, size structure and current direction. Scavenger aggregation dynamics and behaviour on carcasses in the Arctic Ocean differ from those in other reported deep-sea areas in arrival time at bait, abundance and length distribution of individuals sampled. The giant amphipod Eurythenes gryllus dominated in our bait experiments; it exceeded numbers counted by other workers by $>13$-fold, and the first individuals appeared up to 20 times faster than in other reported experiments. Specimen attraction and abundance seem to be directly linked to the organic input of food falls in the area. Relations between scavenger aggregations and trophic conditions are discussed with respect to results obtained under different trophic regimes in the Arabian Sea and in the Pacific and Atlantic Oceans.
\end{abstract}

KEY WORDS: Deep-sea $\cdot$ Arctic Ocean $\cdot$ Eurythenes gryllus $\cdot$ Scavenger population dynamics

\section{INTRODUCTION}

Studies with baited time-lapse cameras and traps have revealed large, motile, scavenging fauna attracted to carrion in the deep sea all over the world (Dayton \& Hessler 1972, Smith 1985, Witte 1999). Comparing the bait-attending fauna of different areas within the North Atlantic, Mediterranean Sea and Pacific, the scavenger communities have been found to differ in terms of species composition and the numbers of individuals attracted (Priede et al. 1990, Thurston et al. 1995, Christiansen 1996, Priede \& Merrett 1998, Janssen et al. 2000, Legezynska et al. 2000). In the deep sea, scavenging communities are dominated mostly by lysianassoid amphipods and large fish, both highly efficient necrophages (Christiansen et al. 1990, Priede et al. 1991). One of the most important scaveng- ing amphipods attracted to food falls in the deep sea is the cosmopolitan lysianassoid Eurythenes gryllus (Lichtenstein, 1822), which seems to play an important role in biological processes in deep water (Charmasson \& Calmet 1990). For benthic or bentho-pelagic scavengers, the impact of any food fall is unpredictable both in space and in time. Food falls are extremely large local organic carbon enrichments, given the low input rates of other organic matter to the deep sea. Differences are related to differences in surface productivity and the resulting export flux to the deep sea. This link, including availability of food falls, affects population densities and species composition of scavengers (e.g. Smith \& Baldwin 1984, Thurston et al. 1995, Christiansen 1996).

The Fram Strait differs considerably from most other localities in which baited time-lapse camera experi- 
ments have been conducted. It is a seasonally ice-covered area where a cryopelagic fish and invertebrate fauna exists beneath the ice (Gradinger 1998, Poltermann 2001) and seals, being prey organisms of the Arctic top predator Ursus maritimus, rest on the ice. Oceanographic features such as eddies are thought to result in a wider dispersal of the odour plume than in other regions.

Six large food-fall experiments distributed over an area of about $11700 \mathrm{~km}^{2}$ were performed in the Fram Strait in order to investigate the scavenger community, its spatial and temporal distribution and its composition (species, sex ratio, length-frequency distribution).

\section{MATERIALS AND METHODS}

Study sites. The Fram Strait is the only deep connection between the North Atlantic and the Arctic Ocean and plays a significant role in global water mass exchange (Fig. 1). The various topographical structures of the Fram Strait lead to a splitting of the warm and nutrient-rich West Spitsbergen Current, carrying Atlantic water northward, into at least 3 parts. One part enters the Arctic Ocean north of Svalbard (33\%), a second branch flows northward along the northwestern slope of the Yermark Plateau ( $45 \%)$ and the third part (22\%), which for our experiments is the most relevant, recirculates immediately in the Fram Strait at about $79^{\circ} \mathrm{N}$ (Manley 1995, Rudels et al. 2000). This region is characterised by strong annual fluctuations in ice coverage, although the eastern part of the Fram Strait is generally ice free during the summer months (Rudels et al. 2000).

Experimental set-up. A tripod lander equipped with a baited time-lapse camera (Model Simrad Mesotech Photosea 5000), a Photosea 1500SX flash, an acoustic Doppler current profiler (Aanderaa Instruments RCM11), baited traps, glass spheres for buoyancy and ballast weight was used. Two acoustic releases allowed the retrieval of the system after deployment periods lasting between 17.5 and $29.5 \mathrm{~h}$. The camera view was centred on bait exposed on a grid, which was attached to the lander about $15 \mathrm{~cm}$ above the seafloor, covering an area of $0.7 \mathrm{~m}^{2}$. Pictures (Kodak Ektachrome 200, $35 \mathrm{~mm} \times 35 \mathrm{~mm} \times 30 \mathrm{~m}$ ) were taken at 3 min intervals. Six experiments were carried out with this configuration during 2 Arctic expeditions of the German RV 'Polarstern' in the summers of 2000 and 2001 (for details see the respective cruise reports; Krause \& Schauer 2001, Fahrbach 2002). All stations were situated in the Fram Strait, Arctic Ocean (Fig. 1, Table 1).

All traps were made of plastic pipes of $65 \mathrm{~cm}$ length, with a funnel opening of $15 \mathrm{~cm}(3.5 \mathrm{~cm}$ at the end), and 3 of them were partitioned into 2 chambers. While bait was only available in 1 of the chambers, bait odour could penetrate into the neighbouring chamber. About $50 \mathrm{~g}$ of fish was used as bait in each trap. Three traps were fixed horizontally below the grid; 3 others were placed at 1.20 , and another 3 , at $1.50 \mathrm{~m}$ above the seafloor.

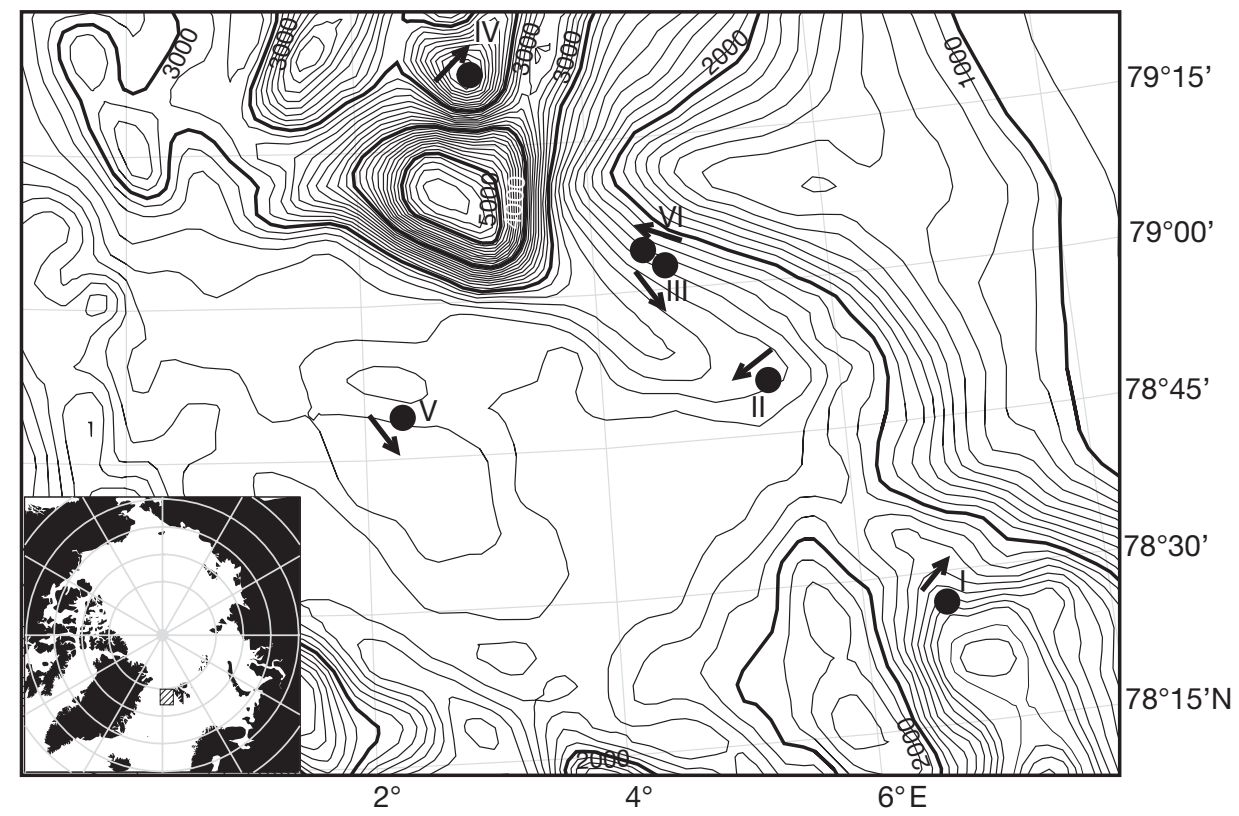

Fig. 1. Locations of Stns I to VI in the Fram Strait, Arctic Ocean. Arrows indicate the main bottom current direction from 1997 to 2002 (Premke et al. 2003, Schauer et al. unpubl. data) 


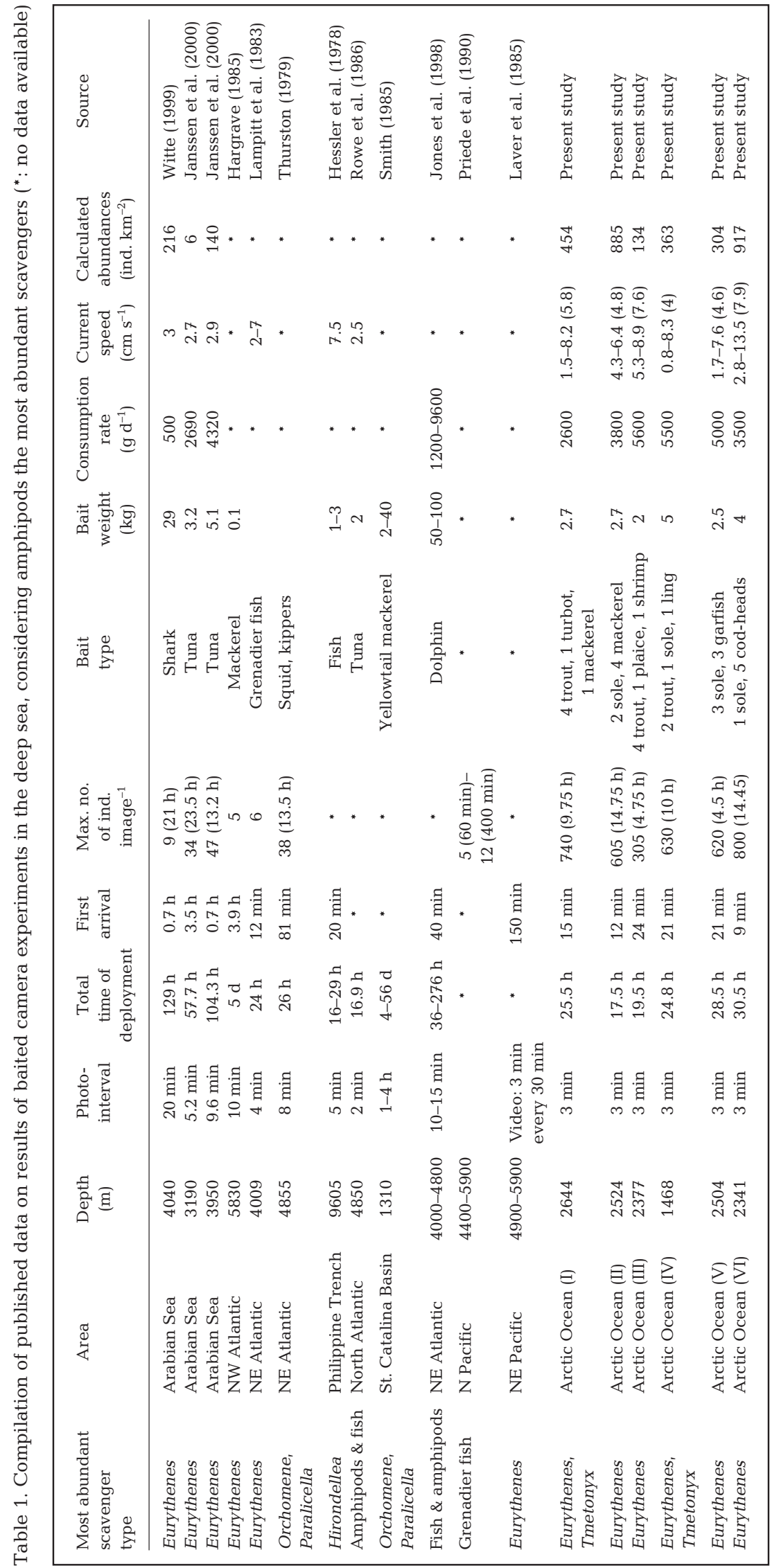

Freshly thawed fishes and a crustacean were used as bait at comparable mass, but in different compositions (Table 1). Aiming to identify food preferences by analyses of the time-lapse photographs, we used the fish species trout Salmo trutta or sole Solea solea as standard bait. Additionally, other species used were turbot Psetta maxima, mackerel Scomber scombrus, plaice Pleuronectus platessa, ling Molva molva, garfish Belone belone and heads of cod Gadus morhua, and in one case a non-fish bait, a natant decapod (with a wet weight of $\sim 50 \mathrm{~g}$ ).

Post-processing of photographs. Slides were examined with a stereomicroscope (Olympus, $10 \times 6.3$ magnification) to identify and quantify all visible organisms. Individuals were counted on each slide at the beginning of observation, then on every tenth slide and, finally, on every fifth slide during dense population structures. Amphipods visible on the slides, almost exclusively Eurythenes gryllus, were easily identified by characteristics such as body shape, colour (red, white and pink) and eye shape. Photographic identification of individuals was difficult, especially in the cases of juvenile E. gryllus and adult, but smaller-sized, Tmetonyx norbiensis. This situation affected data analysis of the photographs. Clearly, the obtained counts of amphipod numbers have to be regarded as a crude minimum estimate. The large number of amphipods attracted in our experiments, as well as their overlapping arrivals and departures after about $4 \mathrm{~h}$, also impeded the determination of the number of frames over which a single individual was present.

The identification was verified by analysis of preserved individuals sampled with the baited traps on the lander. As it was difficult to distinguish between small, presumably juvenile amphipods $(<10 \mathrm{~mm})$ of Eurythenes gryllus and amphipods belonging to the species Tmetonyx norbiensis (Oleröd, 1987) we counted all amphipods $<10 \mathrm{~mm}$ together and used the proportion from captured amphipods 
of E. gryllus and $T$. norbiensis obtained in each experiment to calculate the theoretical respective numbers of these 2 species.

Abundances in the vicinity of the station were also calculated by applying the relationship $\mathrm{n}=C t_{\mathrm{arr}}{ }^{-2}$ (after Priede \& Merrett 1996), where $C$ is a constant (for each experiment) depending on amphipod swimming speed and current speed and $t_{\text {arr }}$ is the arrival time of the first amphipod after the lander reached the sea floor.

Post-processing of trap material. All organisms collected with traps were fixed onboard in $4 \%$ buffered formaldehyde. In the laboratory, animals were rinsed in fresh water and identified to species or genus level. Sex was determined by external characters, the length of each individual was measured to the nearest millimetre from the apex of the head to the tip of the telson under a stereo-microscope while gently straightening the animal. Final measurements were based on an average of 3 readings. All specimens were blotted dry, and their wet weight was measured individually on a microbalance. Because traps were lost during Expt VI, there was no fixed material available from this experiment.

Specimens with oostegites visible under a stereomicroscope were considered to be females. Presence of genital papillae between Pereonite 7 and Pleonite 1 identified males. Individuals without external sexual characteristics were considered to be juveniles. In our study, females and males of Eurythenes gryllus were identified at a minimum length of 15.5 and $17 \mathrm{~mm}$, respectively. It is likely that some individuals within the juvenile category (15.5 to $30 \mathrm{~mm}$ ) were unrecognised females, because oostegites are difficult to detect in the very early stage of development. They were included in a second category comprising the female and larger juvenile specimens, assuming that all 'juveniles' $\geq 15.5 \mathrm{~mm}$ were unrecognised females.

\section{RESULTS}

\section{Lengths and abundances of amphipods}

Lander Deployments I to V collected 4200 amphipod individuals belonging to 3 species. About 700 specimens were taken randomly from the total sample for further genetic and lipid analyses, resulting in 3494 amphipods for this study, including 2003 individuals of Eurythenes gryllus, 1483 individuals of Tmetonyx norbiensis and 8 individuals of Stegocephalus sp.

\section{Eurythenes gryllus}

The mean lengths of males, females, females plus juveniles and juveniles were calculated for all experiments (Table 2). Comparing mean length of adult females $(34.1 \mathrm{~mm})$ from all 5 stations to mean length of adult males (34.3 $\mathrm{mm})$, there were no significant differences (ANOVA, $p>0.05$ ). Considering those juveniles $\geq 15.5 \mathrm{~mm}$ to be females, statistical differences become significant. Among the stations, significant differences were found in Expt IV, where females are larger than males, and in Expt V, where males are larger than females.

Comparisons were also made for the length range of adult females and males at all of the 5 locations sampled. Despite similar mean body length of the 2 sexes, it is obvious that females grow to be larger, with the largest female collected $75 \mathrm{~mm}$ and the largest male $56 \mathrm{~mm}$ long (Fig. 2, Table 2).

The mean body lengths are about 17 and $11 \mathrm{~mm}$ for all juveniles and without juveniles $\geq 15.5 \mathrm{~mm}$, respectively (Fig. 3). Juveniles $<15.5 \mathrm{~mm}$ were found in Expts I, II and IV. No juveniles $<15.5 \mathrm{~mm}$ were found at Stns II and V (Table 2).

In Expts III and V fewer amphipods were caught than in Expts I, II and IV. Mean length of females at both stations was similar (34 mm/31.6 mm), but the mean length of males $(33.8 \mathrm{~mm} / 43.2 \mathrm{~mm})$ was significantly different (Figs. 2 \& 3). The low number of captured amphipods (of both sexes) was also reflected in the photographic data, where the lowest number of amphipods occurred (Fig. 4).

\section{Tmetonyx norbiensis}

The mean sizes of males, females, ovigerous females and juveniles were determined (Table 2). High num- 
bers of T. norbiensis were captured only in Expts I and IV (see Table 3). Samples from Expt III contained only 5 individuals: 3 females ( 2 of them ovigerous) and 2 males, with a mean body length of $26.3 \mathrm{~mm}$ (females) and $25.5 \mathrm{~mm}$ (males).

The smallest females and males identified were 8 and $10 \mathrm{~mm}$, respectively. Because of a lack of external characters, 4 ind. were considered to be juveniles.

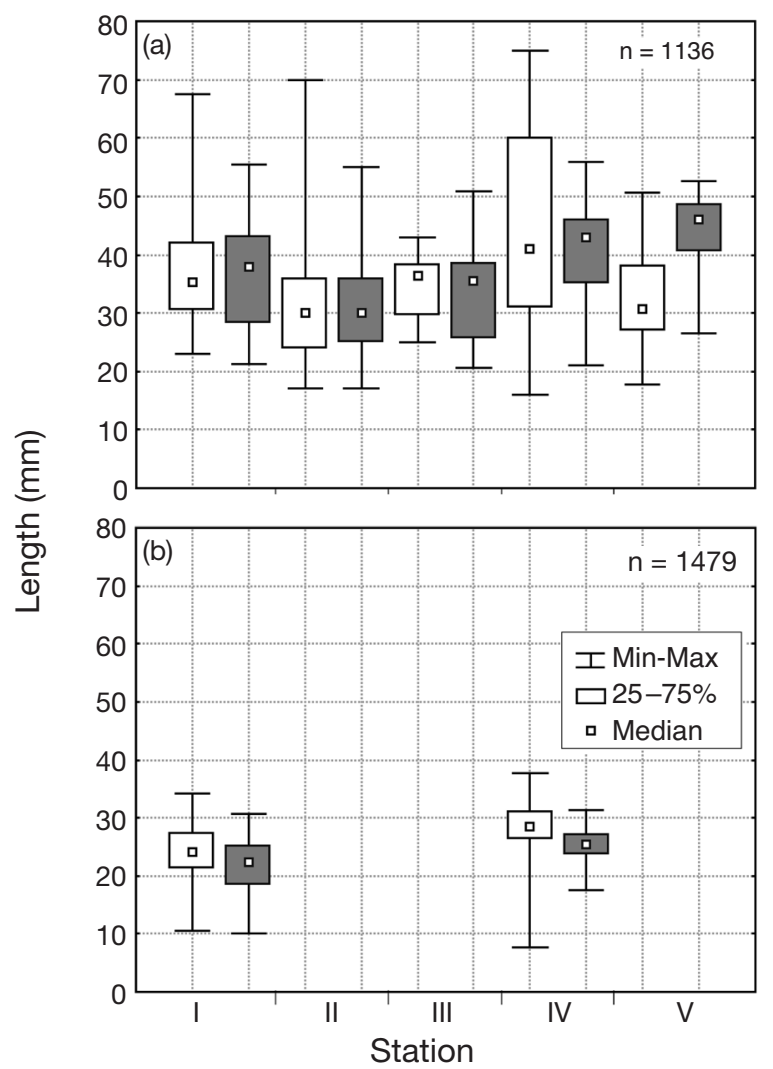

Fig. 2. (a) Eurythenes gryllus and (b) Tmetonyx norbiensis. Box and whisker plot of lengths $(\mathrm{mm})$ of mature females excluding juveniles (white boxes) and males (grey boxes)

Table 3. Eurythenes gryllus and Tmetonyx norbiensis. Sex ratio of specimens in each experiment. $\mathrm{N}$ indicates the total number of males and females. Numbers in parentheses are total numbers and sex ratios for E. gryllus when juveniles $\geq 15.5 \mathrm{~mm}$ (assumed to be unidentified females) were included. -: no individuals caught

\begin{tabular}{|lcccc|}
\hline & \multicolumn{2}{c}{ Eurythenes gryllus } & \multicolumn{2}{c|}{ Tmetonyx norbiensis } \\
& $\mathrm{N}$ & $\mathrm{M}: \mathrm{F}$ & $\mathrm{N}$ & $\mathrm{M}: \mathrm{F}$ \\
\hline Expt I & $191(430)$ & $1: 0.45(1: 2.26)$ & 257 & $1: 1.54$ \\
Expt II & $583(799)$ & $1: 0.86(1: 1.54)$ & - & - \\
Expt III & $44(57)$ & $1: 0.46(1: 0.90)$ & 5 & $1: 1.50$ \\
Expt IV & $264(330)$ & $1: 0.74(1: 1.18)$ & 1217 & $1: 2.99$ \\
Expt V & $54(59)$ & $1: 1.25(1: 1.45)$ & - & - \\
Total & $1136(1675)$ & $1: 0.75(1: 1.58)$ & 1479 & $1: 2.63$ \\
\hline
\end{tabular}

Females grew to be larger than males, with the largest female captured $38 \mathrm{~mm}$, and the largest male, $31 \mathrm{~mm}$ (Fig. 5).

\section{Spatial distribution and aggregation dynamics of the scavenger community on bait}

Scavengers captured with traps or determined on photographs belonged to 5 taxa (Table 1). The scavenger community on our photographs was dominated numerically by the lysianassoid amphipod Eurythenes gryllus followed by Tmetonyx norbiensis, the latter in considerably lower abundance. A third amphipod species, Stegocephalus sp., appeared rarely (single individuals). Other organisms detected on the photographs were zoarcid fish and chaetiliid isopods.

In 5 of our experiments the amphipod Eurythenes gryllus was the most abundant species, both in traps and on photographs. In the traps of Expt IV the number of Tmetonyx norbiensis individuals exceeded those of E. gryllus by a factor of close to 4 (Figs. 3 \& 5). Although T. norbiensis was captured frequently in 2 of the 6 experiments, this species was identified on photographs in much lower abundances.

The zoarcid fish Lycodes cf. frigidus appeared occasionally on photographs in all experiments, with a maximum of 6 individuals per photograph (Table 1). During 1 experiment 2 fish entered 1 of our traps that was oriented towards the camera. The bait inside the trap had, at this point, been nearly consumed, and most of the trapped Eurythenes gryllus had escaped (the funnel opening was obviously too large). One fish specimen left the trap after a while, but the remaining fish was finally (after $8 \mathrm{~h}$ ) attacked by the few E. gryllus that were still inside the trap. The subsequent release of body fluids of the wounded fish attracted 100s of new amphipods, and the fish was skeletonised within $11 \mathrm{~h}$.

The isopod Saduria sabina and the amphipod Stegocephalus sp. were identified only occasionally on the photographs and only a single individual of Stegocephalus sp. was captured. In all of the experiments amphipods were found on the surface of the bait. Bait was consumed completely, after a minimum of 12 and a maximum of $28 \mathrm{~h}$, leaving clean skeletons only (Table 1).

First arrivals of single individuals of Eurythenes gryllus were recorded after a 15, 12, 24, 21, 21 and 9 min time at bottom (tab) (Expts I-VI, respectively; Table 1). The maximum number of individuals differed from experiment to experiment (Fig. 4), but we also recorded differences in the time of arrival of individuals that are considered to show 2 patterns of feeding aggregations: 

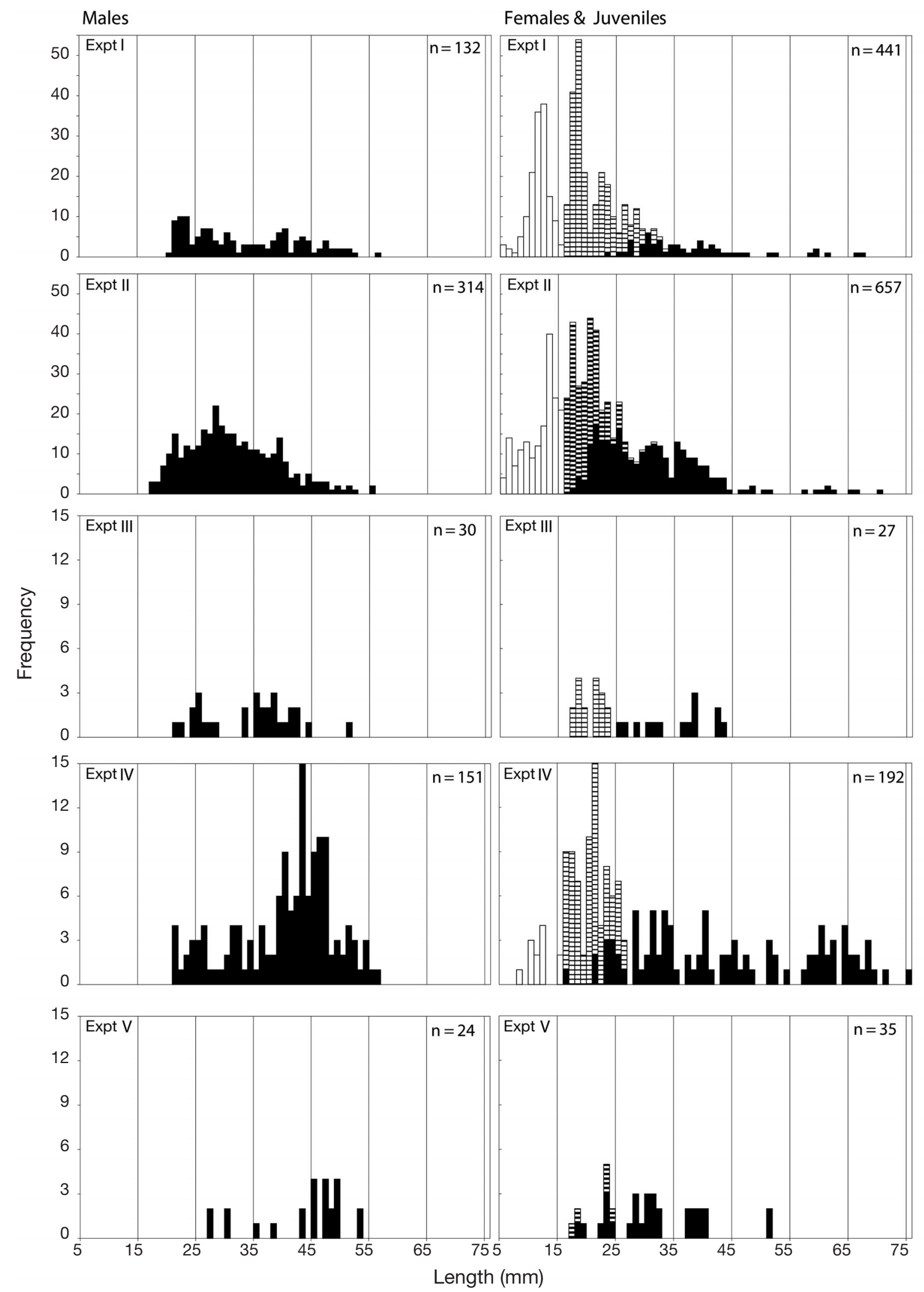

Fig. 3. Eurythenes gryllus. Length-frequency distributions from 5 stations in Fram Strait based on total body length. Left panels: males (black); right panels: females (black), juveniles $\geq 15.5 \mathrm{~mm}$ (striped) and juveniles $<15.5 \mathrm{~mm}$ (white). Note the different scales on the $y$-axis 
Type A
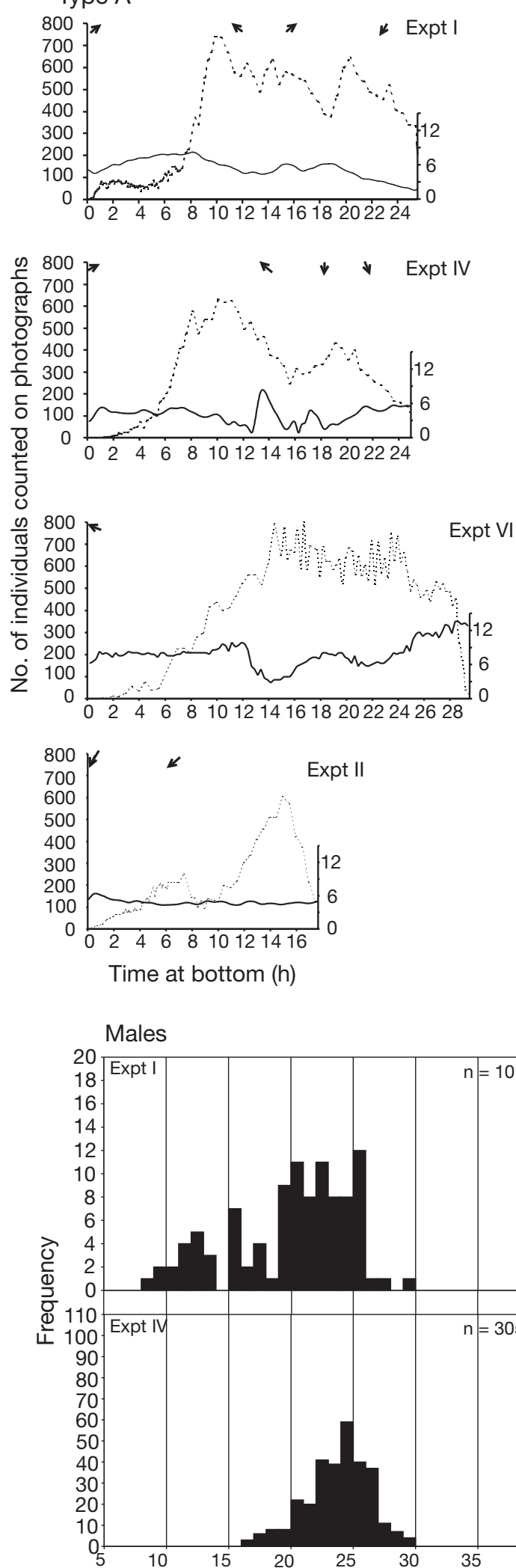

Type B
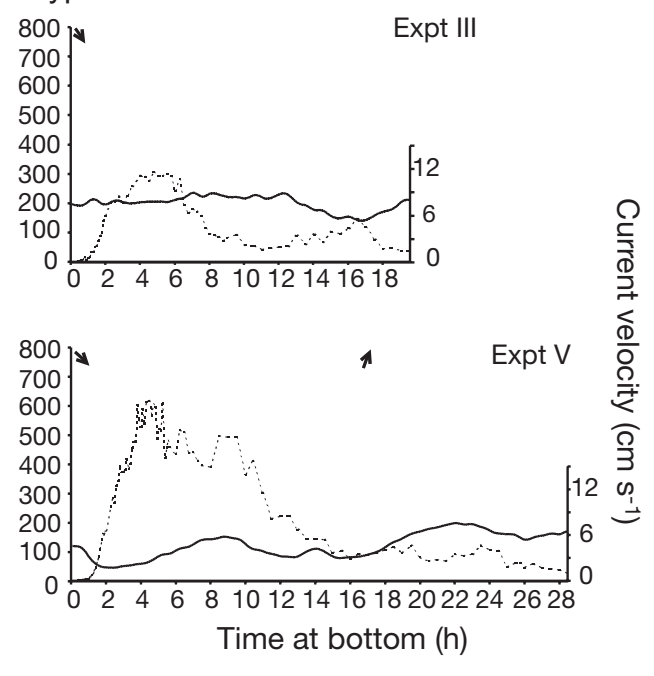

Time at bottom (h)

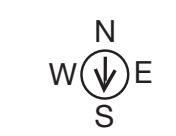

Current direction

Fig. 4. Eurythenes gryllus. Temporal patterns of numbers of amphipods (dashed line) as the most abundant scavenger counted on photographs from 6 stations in Fram Strait and the current velocity (black line) of each experiment (right axis numbers). Arrows indicate change of current direction, with cardinal directions given by rosette

Females \& Juveniles

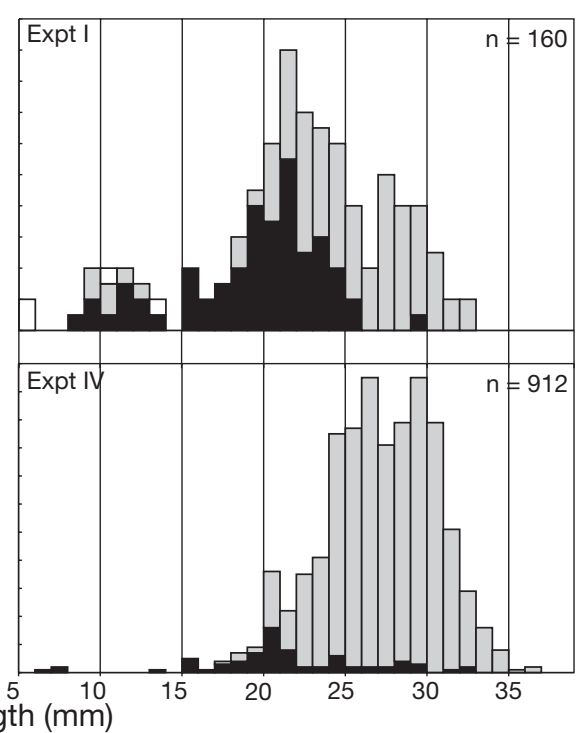

Fig. 5. Tmetonyx norbiensis. Length-frequency distributions based on total body length. Left panels: males (black); right panels: females without eggs (black), ovigerous females (grey) and juveniles (white). Note the different scales on the $y$-axis 
Type A-maximum numbers of individuals present between 10 and $24 \mathrm{~h}$ tab, with a maximum number of 600 to 800 ind. $0.7 \mathrm{~m}^{-2}$ (Fig. 4, Expts I, II, IV, VI);

Type B-maximum numbers of individuals present between 3 and $6 \mathrm{~h}$ tab, with a maximum number of 300 to 600 ind. $0.7 \mathrm{~m}^{-2}$ (Fig. 4, Expts III, V).

In both types, the feeding communities were dominated by large individuals during the first hours of tab and the majority of large individuals had left the food fall $4 \mathrm{~h}$ after the arrival of bait deployments at the sea floor. A permanent coming and going of individuals suggested a rather short retention period at food falls, but we were unable to identify repeated visits by single specimens.

Generally, large amphipods appeared first, followed by a second peak of smaller individuals. The Type A aggregation is shown by Expt II, in which large individuals primarily dominated during the first $4 \mathrm{~h}$. About $10 \mathrm{~h}$ later, the maximum peak of amphipods (600 ind. $0.7 \mathrm{~m}^{-2}$ ) consisted mainly of smaller individuals (Fig. 4, Expt IV). The current flow during the first $4 \mathrm{~h}\left(5.4 \mathrm{~cm} \mathrm{~s}^{-1}\right.$ on average) was only slightly higher than later $\left(4.8 \mathrm{~cm} \mathrm{~s}^{-1}\right.$ on average). The opposite is illustrated in Fig. 4 (Expt III showed a Type B aggregation). Current speed was fairly constant throughout the experiment $\left(7.6 \mathrm{~cm} \mathrm{~s}^{-1}\right.$ on average), and the number of amphipods reached a maximum of 300 (mostly larger) ind. $0.7 \mathrm{~m}^{-2}$ after $4.75 \mathrm{~h}$ tab. After $6 \mathrm{~h} \mathrm{tab}$, the abundance declined to a few individuals, but than increased again to 150 (mostly smaller) ind. $0.7 \mathrm{~m}^{-2}$ by $16.5 \mathrm{~h}$ tab. In contrast to Expt II, the majority of small individuals attending Expt III did not account for the maximum abundance during this experiment (Fig. 4, Expt III).

Abundances of Eurythenes gryllus calculated from the time of first arrival were: $454 \mathrm{~km}^{-2}$ (Stn I), $885 \mathrm{~km}^{-2}$ (Stn II), $134 \mathrm{~km}^{-2}$ (Stn III), $363 \mathrm{~km}^{-2}$ (Stn IV), $304 \mathrm{~km}^{-2}$ (Stn V) and $917 \mathrm{~km}^{-2}$ (Stn VI). The stations with high abundances of E. gryllus (Stns I, II, IV and VI) are Type A aggregations, while those with low abundances (Stns III and V) belong to Type B.

\section{Food preferences and consumption rate}

By counting individuals at bait species over time, we identified a pronounced preference for round fish species over flat fish species in Eurythenes gryllus. Among the round species, trout is preferred over ling, and other round fish species are attacked with equal facility. In Expt IV, the first scavenging amphipods fed on trout, those following 30 min later fed on ling and, about $1 \mathrm{~h}$ later, new arrivals at the bait started to feed on sole. Amphipods consumed the trout within $8.5 \mathrm{~h}$ tab, and $4 \mathrm{~h}$ later the sole was skeletonised. The species that served longest as bait was the ling, the total consumption of which required $22 \mathrm{~h}$ (Fig. 6).

The consumption rate differed among stations, and ranged from 2500 to $5500 \mathrm{~g} \mathrm{~d}^{-1}$. Consumption at Stn III was divided into 2 rates: for the entire experiment, including the relatively tiny and light shrimp, it amounted to about $2500 \mathrm{~g} \mathrm{~d}^{-1}$, but it amounted to a rate of $5600 \mathrm{~g} \mathrm{~d}^{-1}$ if only fish were considered.

As illustrated in Fig. 4 (Expts III and V), the number of amphipods increased quickly after deployment of the lander at the seafloor during these 2 experiments, and rapid consumption of the bait followed, so that most of the bait was consumed within $10 \mathrm{~h}$. This rapid bait consumption at Stns III and V is related to the early peak abundance of Eurythenes gryllus (Type B). Although, in contrast to other deployments, the bait wet weight was lower in Expts III and V, i.e. 2 and $2.5 \mathrm{~kg}$, respectively, the consumption rate was high in Expt V (with $5000 \mathrm{~g} \mathrm{~d}^{-1}$ ) and even the highest calculated in Expt III (5600 $\mathrm{g} \mathrm{d}^{-1}$, excluding the small shrimp). With bait wet weight ranging between 2.7 and $5 \mathrm{~kg}$ in the other experiments, consumption rates in experiments of Type A were relatively low (2600 to $\left.3800 \mathrm{~g} \mathrm{~d}^{-1}\right)$, except at Stn IV (5500 $\left.\mathrm{g} \mathrm{d}^{-1}\right)$.

\section{Sex ratio}

The ratio of males to females was determined for each location (experiment), and for all stations combined. From a reproductive point of view the most important sexual ratio is the number of mature males to mature females. For Eurythenes gryllus, this comparison favours mature males 1:0.7, all experiments combined (Table 3). Females of E. gryllus carrying eggs were never captured. The sex ratios of Tmetonyx norbiensis strongly favoured females 2.6:1, all experiments combined (Table 3). Because of low abundances, Stn III was not considered. Generally, ovigerous females were more frequent than females without eggs.

\section{Eurythenes gryllus}

There is also a length-sex correlation between the stations, which appears similar. Female body lengths of E. gryllus at Stn II, which were relatively small at the 25 to $75 \%$ level (box \& whisker plot) compared to other stations, coincide with small body lengths for males at this station. Both males and females at Stn IV contained the largest individuals (Fig. 2). There was, however, a considerable difference between the sexes at Stn V. 

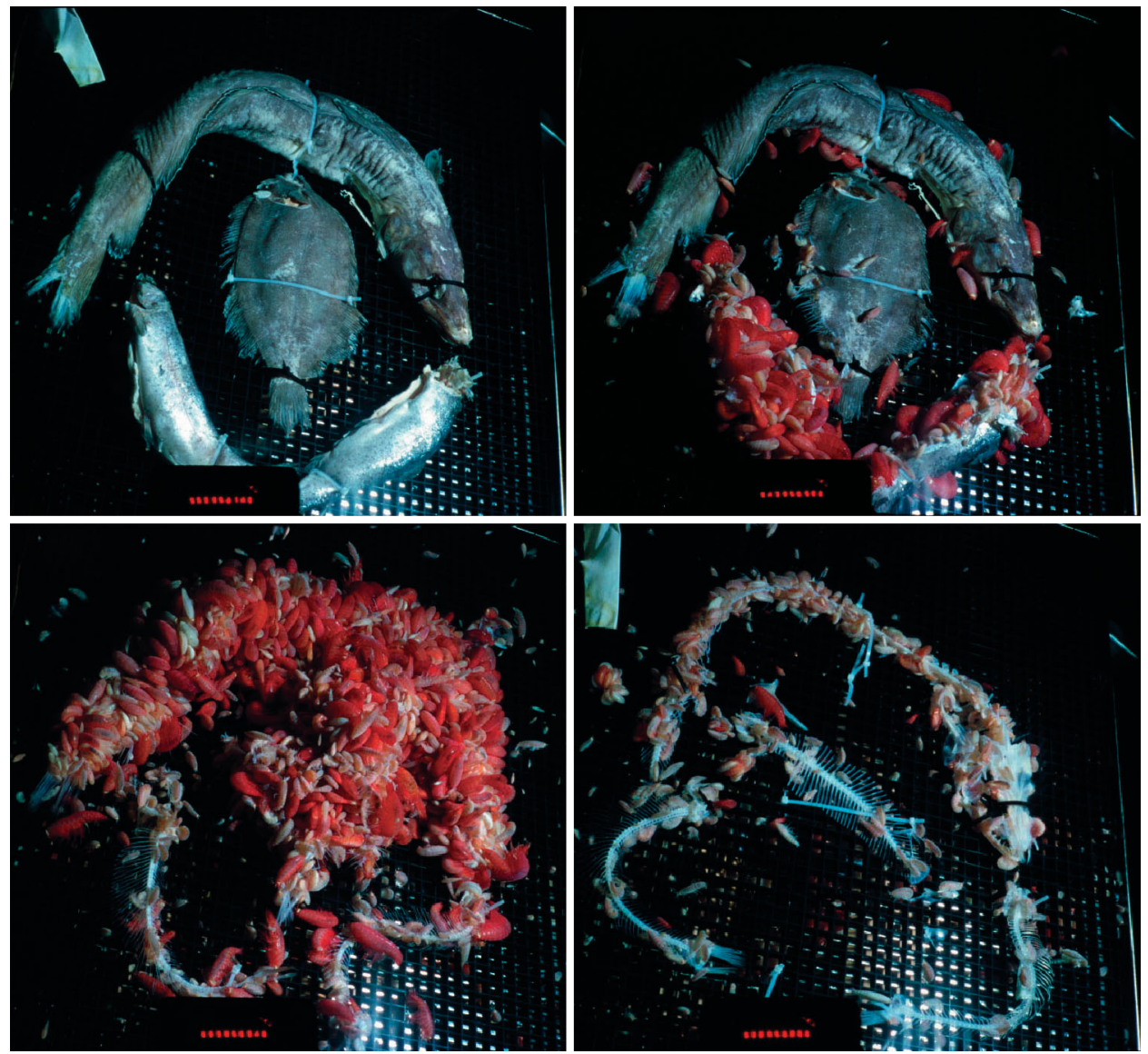

Fig. 6. Example of a scavenger aggregation at Stn IV. Time-lapse photographic sequence at time intervals of $0,6,10$ and $22.5 \mathrm{~h}$ (time at bottom). Red, white and pink organisms were amphipods

\section{Tmetonyx norbiensis}

There is also a length-sex correlation between the stations. Females and males of T. norbiensis at Stn I were smaller than those at Stn IV. For both species there is a correlation between photographic abundances and numbers of amphipods captured. Fewer amphipods of Eurythenes gryllus on photographs correspond to fewer amphipods captured in traps (Fig. 4).

\section{DISCUSSION}

For a long time the seafloor of the deep sea was considered to be a monotonous, desert-like environment colonised by only a few organisms because of the high hydrostatic pressure, low temperature, absence of light and limited food supply (Svedrup et al. 1942, Dayton \& Hessler 1972, Somero et al. 1983). Scientific results obtained during the second half of the last century led to a shift in the understanding of the deep-sea eco- system (Sanders 1968). The deep-sea benthos was thought to be common and decoupled from processes such as primary and secondary production in the water column. We know today that this is only partly true and that the deep-sea benthos may temporally or spatially receive larger amounts of organic material from either aggregated phytoplankton (Thiel et al. 1989, Pfannkuche et al. 1999) or carcasses of medium- and largesized invertebrates and vertebrates (Smith et al. 1989, Britton \& Morton 1994, Klages et al. 2001) than previously assumed. Studies in the north-eastern Atlantic revealed that macroaggregates settling from the euphotic zone at a rate of 100 to $150 \mathrm{~m} \mathrm{~d}^{-1}$ lead to a deposit of phytodetritus on the sediment surface. Time-lapse camera experiments in different regions of the world's oceans demonstrated that the deep-sea benthic community responds rather quickly to such food supply (Rice et al. 1994). Phytodetrital material is colonised rapidly by Bacteria and Protozoa (flagellates and foraminifers), and is ingested by large depositfeeding animals (Gooday \& Turley 1990). 


\section{Methodology}

Baited time-lapse camera experiments form a useful approach to studying the deep-sea scavenger community, because they allow a precise simulation of a naturally occurring event in the deep sea. Most of the studies summarised in Table 1 using baited traps (Thurston et al. 2002) worked on single-experiment data sets, with different kinds and masses of bait, so any differences in composition and succession of the motile scavenger community might have been masked. It should be kept in mind that in our experiments captured organisms permitted reliable species or genus identification.

\section{Natural food falls}

The role of carcasses as a mechanism for the transfer of organic matter into the deep sea is still under discussion. Smith et al. (1989, and references cited therein) discussed the migratory routes of grey whales Eschrichtius robustus along the west coast of North America and concluded that the random distribution of whale carcasses due to natural mortality would lead to an average distance between falls of about $9 \mathrm{~km}$. In another study Smith (1985) calculated that large nekton falls ( 2 to $40 \mathrm{~kg}$ ) contribute only about $4 \%$ of the energy needs of the scavenging ophiuroid Ophiophthalamus normani in the Santa Catalina Basin at about $1300 \mathrm{~m}$ water depth. The problem with such calculations is that they are based mostly on remains detected along video surveys. As the highly motile scavenger community detects and consumes food parcels very rapidly, the probability of detecting active feeding or evidence of such parcels is rather low (Klages et al. 2001, Soltwedel et al. 2003). Ocean bottom seismometers record infrequent micro-seismic events of unknown origin, which may be related to the impact of falling carcasses (W. Jokat, AWI, pers. comm.). This kind of impact may be detected by scavenging invertebrates even at distances far beyond $100 \mathrm{~m}$ (Klages et al. 2002).

\section{Abundances}

The scavenging community of the deep Arctic Ocean was found to quickly discover and rapidly consume bait, as has been reported from other deep-sea areas (Hessler et al. 1978, Lampitt et al. 1983, Laver et al. 1985, Smith 1985, Rowe et al. 1986, Vinogradov \& Vinogradov 1991). It was dominated by Eurythenes gryllus and Tmetonyx norbiensis. To analyse still photographs from the time-lapse camera, we used a grid some $15 \mathrm{~cm}$ above the seafloor instead of deploying the fish bait directly on the bottom. This implies that the number of individuals being counted on each photograph is a minimum value, because we cannot rule out the possibility that some amphipods are concealed by others and that even more individuals may be below the grid. Nonetheless, we counted an extraordinary abundance of individuals of E. gryllus on our pictures.

As the number of amphipods on pictures gives no indication of the abundances in the vicinity of the stations, we calculated such abundances by applying the equation of Priede \& Merrett (1996). These authors found that times of first arrivals of abyssal macrourids Coryphaenoides armatus correlated well with data of trawled fish density. By using this equation, the average bottom current speed for each experiment and the mean amphipod swimming speed $\left(7.3 \mathrm{~cm} \mathrm{~s}^{-1}\right.$; Laver et al. 1985) enable us to calculate abundances of Eurythenes gryllus in the vicinity of the lander (Table 1); these calculations assume that the amphipods are not static, but swim continuously (Bregazzi 1973), so that the narrow odour plume never passes between the 2 nearest amphipods, but that one or the other will intercept the plume and move towards the bait. Given that at Stns I, III, IV and V the maximum of counted individuals on pictures was twice that of calculated abundances (Table 1), we could assume that the radius of approaching amphipods is $>1 \mathrm{~km}$.

\section{Frequency of occurrence}

Aggregation dynamics suggest that natural food falls are quite common in the area of investigation; otherwise, the population density would be lower. In a recent study Soltwedel et al. (2003) reported on a video transect close to our area of investigation prepared with a towed system. Along the $17.5 \mathrm{~km}$ transect covering an area of about $13500 \mathrm{~m}^{2}$, a single fish skeleton (length $36 \mathrm{~cm}$ and biomass approximately $0.5 \mathrm{~kg}$ wet weight) was identified on 1 underwater photograph at $1280 \mathrm{~m}$ water depth. This scarcity of observed remains of natural food falls on underwater photographs seems to be in contrast to the assumption of frequent events. On the other hand, our time-lapse camera experiments, as do those of others, clearly demonstrate that Eurythenes gryllus feeds rapidly on available food sources. The probability of locating a scavenger in an ongoing feeding process or of finding the remains of a food fall decreases with time (Rowe et al. 1986). Whale skeletons have been found in different regions of the ocean (Naganuma et al. 1996, Smith et al. 1998), but surprisingly no such observation has been made for the Arctic. Polar bears Ursus maritimus hunting for seals 
live in the Fram Strait, which is covered with ice for several months of the year. The population density of bears in our area of investigation during the winter months is unknown, but bears occur frequently on the Svalbard, which is only about $150 \mathrm{~km}$ east of our study site. Wounded or dead seals attacked by polar bears are expected to settle to the seafloor, but no bones were discovered during our video transects.

Many lysianassoid amphipods are marine cold-water inhabitants and some of them contribute significantly to the Antarctic and Arctic benthos (Arntz et al. 1994, De Broyer \& Jazdzewski 1993). In the Antarctic, other top predators such as leopard seals Hydrurga leptonyx and killer whales Orcinus orca hunt for penguins, whose remains certainly also serve as food for scavengers. The higher trophic level organisation of polar ecosystems compared to more oligotrophic regions, like the central Pacific Ocean, the Arabian Sea or the North Atlantic, with less abundant mammals, could explain the high number of Eurythenes gryllus (and other scavenging amphipod species) attending our bait experiments. A tendency for E. gryllus to occur in higher numbers in more productive waters such as the North Pacific and Atlantic Ocean compared to oligotrophic waters like the open Pacific was also observed by other authors (e.g. Thurston 1990, Christiansen 1996).

\section{Aggregation dynamics}

Two categories (Types A \& B; Table 4) of scavenger aggregations were introduced in this study, one describing a fast-responding community, with larger individuals appearing and leaving first, and a second one arriving later, with lower numbers of individuals. The reasons for this difference are difficult to assess. Attending food falls is a risk to the individuals because cannibalism can occur, an argument that has been used to explain the absence of ovigerous females at such sites (Ingram \& Hessler 1987). Amphipods are at risk of predation by attendant fish (e.g. Lampitt et al.
1983). Furthermore, developing gonads or eggs laid in the marsupium prevent gut expansion or risk the loss of the brood, thus limiting food intake (Hargrave et al. 1994). Even predatory fish are endangered when confined in the presence of voracious scavengers when food decreases in quantity (Walker 1907, RakusaSuszczewski 1982), as we noted in our unpublished time-lapse photography observation of a zoarcid fish being killed by Eurythenes gryllus while captured in a trap.

The strategy of 'tank-topping', a behaviour describing feeding at a carcass until the stomach is filled, resting close by and feeding again after defecation, can be rejected for most of the large individuals of the Type A category, because the size spectra clearly show that smaller individuals dominate the aggregation towards the end of the experiments.

\section{Consumption rates}

Rates of bait consumption were similar to those found in the deep Arabian Sea (Janssen et al. 2000). In the North Atlantic, bait consumption rates were considerably faster; however, in that area, amphipods were not the only organisms in the scavenger community and carcass wet weights were up to $100 \mathrm{~kg}$ of dolphin (Jones et al. 1998; Table 1).

The influence of different kinds of food offered has been studied, and striking differences in the consumption of tuna and shark have been found (e.g. Jannasch 1978). In our experiments, the species which lasted longest as bait was the ling, the total consumption of which required $22 \mathrm{~h}$ tab; however, this can be simply explained by the differences in wet weight of trout and sole as compared to ling, which was 4 times heavier (Fig. 6). The same was observed in Expt V, where the cod heads were preferred, but finally devoured later as a result of their larger size. Due to the robust skin of flat fish, we observed food preferences for round fish as compared to those of flat fish, but no preferences within round fish.

Table 4. Grouping of all stations (except Stn VI) in 2 different types, based on camera, trap and current meter data analysis

\begin{tabular}{|ll|}
\hline Type A & Type B \\
\hline High maxima $\left(600-800\right.$ ind. $\left.0.7 \mathrm{~m}^{-2}\right)$ & Low maxima $\left(300-600\right.$ ind. $\left.0.7 \mathrm{~m}^{-2}\right)$ \\
High calculated abundances $\left(454-885 \mathrm{~km}^{-2}\right)$ & Low calculated abundances $\left(134-304 \mathrm{~km}^{-2}\right)$ \\
Slow increase of scavengers to maximum $(10-24 \mathrm{~h})$ & Fast increase of scavengers to maximum $(3-6 \mathrm{~h})$ \\
Low consumption rate $\left(2600-3800 \mathrm{~g} \mathrm{~d}^{-1}\right)$ & High consumption rate $\left(5000-5300 \mathrm{~g} \mathrm{~d}^{-1}\right)$ \\
Inconstant current direction $(\mathrm{SSW}, \mathrm{SE}, \mathrm{NNE})$ & Constant NNW current direction \\
Juveniles caught & No juveniles caught \\
Tmetonyx norbiensis caught & No Tmetonyx norbiensis caught \\
\hline
\end{tabular}




\section{Functional groups in scavengers}

There are differences in the dominance and behaviour of Eurythenes gryllus and Tmetonyx norbiensis. Large individuals of E. gryllus arrived first, in high numbers, at freshly exposed bait and ingested large amounts within a short period of time, which may be a way of avoiding either competition with or predation by fish. It could also be a function of size and evolution. Hargrave (1985) also observed that amphipods arriving during the first $12 \mathrm{~h}$ were larger than those arriving subsequently. Eurythenes stores food reserves as lipids, resulting in individuals attaining a state close to neutral buoyancy. In contrast, bathyal species of Tmetonyx do not seem to be neutrally buoyant. Neutral buoyancy gives E. gryllus an advantage over T. norbiensis, as it can therefore swim continuously with comparatively little effort, actively search for food falls, and once an odour trail is tracked, arrive earlier at the carcass (Smith \& Baldwin 1982, Sainte-Marie \& Hargrave 1987). The deep-sea lysianassoids can be divided into 2 functional groups on the basis of morphological and physiological criteria (Sainte-Marie 1992). Individuals in the first group, including E. gryllus, are characterised not only by their voracity, but also by morphological, anatomical and physiological adaptations linked to their scavenging mode of life (Dahl 1979, Smith \& Baldwin 1982). They have low metabolic rates, mandibles with a broad, shearing incisor, a large corpus mandibulae and a non-triturative molar process, and capacious guts modified for rapid batch-process feeding. They process food in large pieces passed into the oesophagus without trituration and may survive long periods without feeding (Dahl 1979, Thurston 1979). These species are assumed to utilise food at high assimilation efficiencies (Hargrave 1985, De Broyer \& Thurston 1987). Individuals in the second group (Orchomene [s.l.] spp., T. norbiensis, etc.) have higher metabolic rates (Smith \& Baldwin 1982), less specialised mandibles with a narrow, flat corpus mandibulae and grinding molar and rather small guts. They appear to be generalist feeders (Sainte-Marie et al. 1989), processing food in a more or less continuous way as small and triturated bites, and can survive only short periods of starvation (Dahl 1979, Thurston 1979, Sainte-Marie 1984). This could explain the high abundances of the obligate scavenging amphipod E. gryllus at 3 stations versus the infrequent occurrence of $T$. norbiensis.

\section{Sex ratio}

For Eurythenes gryllus the sex ratio of mature males to mature females was almost equivalent; all experiments combined (Table 3). An equal sex ratio confirms the expectations of a continuously breeding population. This sex ratio coincides with that found in the North Atlantic Ocean (Charmasson \& Calmet 1987, Christiansen et al. 1990), but is markedly different from that found in the north-eastern Pacific (Baldwin \& Smith 1987), in the central North Pacific (Ingram \& Hessler 1987) and in the south-eastern Pacific at a depth of $7800 \mathrm{~m}$ (Thurston et al. 2002), where females dominate. In our collections only Stn V showed preponderance of females.

The sex ratio of Tmetonyx norbiensis strongly favoured females (1:2.6, all experiments combined; Table 3). Also, in the eastern North Atlantic at a depth of $4855 \mathrm{~m}$, males of Orchomene gerulicorbis and $O$. cavimanus were outnumbered by females (Thurston 1979). Generally, ovigerous females of T. norbiensis were found more frequently than females without eggs. Breeding females of Eurythenes gryllus have been reported only once (Thurston \& Bett 1995), which might be an indication of a different way of life compared to T. norbiensis.

\section{Vertical migration}

The ontogenetic migration postulated for Eurythenes gryllus (Christiansen et al. 1990) may be complex. With increasing size, immature E. gryllus move up into the water column, adopting an abysso-pelagic rather than a benthic lifestyle (Ingram \& Hessler 1983, Smith \& Baldwin 1984, Charmasson \& Calmet 1987, Christiansen et al. 1990). Our area of investigation exhibits a complex topography, which has an influence on the mesoscale current regime. A number of eddies have been detected over the past years, some of which circulate in the opposite direction to others close by (Schauer et al. 2004). Such current conditions have an effect on the dispersal of the food odour. The horizontal extent and the rate of dispersion of an odour trace should increase with distance from the bottom, because current velocity and horizontal eddy diffusion rates normally increase from the bottom to the top of the Ekman layer, thus benefiting the amphipods in the water column relative to epibenthic scavengers (Ingram \& Hessler 1983). As chemoreception is the main sense involved in food-fall localisation at distances of 10 s or even 100 s of metres in scavenging crustaceans (Premke et al. 2003), the current conditions of the Fram Strait might favour a scavenger mode of life. If brooding takes place high in the water column and the offspring is released near the sea bed, it might be considered an iteroparous species (Ingram \& Hessler 1987). Also, residence at depths $>1000 \mathrm{~m}$ above the sea bed could remove brooding females from the foraging range of predatory abyssal fish. 
Adult red females are at less risk from pelagic predators because these mostly use photoreception for foraging, as opposed to abyssal predators which use mechanoreception. Furthermore, ovigerous females may not feed on or actively avoid carcasses to reduce predation (Hessler et al. 1978, Baldwin \& Smith 1987).

\section{Length-frequency distribution}

In all our investigations combined, females of Eurythenes gryllus have a larger mean size compared to males. This difference is not statistically significant if we assume that individuals grouped in the 'juveniles $\geq 15.5 \mathrm{~mm}^{\prime}$ category are unidentified females. The largest females caught measured $75 \mathrm{~mm}$ in length, while the largest male was $56 \mathrm{~mm}$ long. These sizes are much smaller than those found in the North Atlantic, where the largest female measured $130 \mathrm{~mm}$ and the largest male $90 \mathrm{~mm}$ (Christiansen et al. 1990), and in the central North Pacific, where the largest recorded female and male were 154 and $122 \mathrm{~mm}$, respectively (Baldwin \& Smith 1987). All the above-mentioned studies were based on traps deployed on the sea floor and in the water column to $500 \mathrm{~m}$ above bottom or more. In all of these studies small individuals were captured almost exclusively on or near the sea floor, but larger organisms were distributed throughout the water column. Sizes similar to those we found were mentioned only from the upwelling area in the southeastern Pacific (Thurston et al. 2002). Significant data are available on the size structure of Eurythenes populations from various widely separated localities (Bowmann \& Manning 1972, Thurston 1979, Baldwin \& Smith 1987, Charmasson \& Calmet 1987, Ingram \& Hessler 1987, Christiansen et al. 1990, Thurston \& Bett 1995, Christiansen 1996, Thurston et al. 2002). A comparison of size at the onset of maturity with earlier results would be appropriate. Also, in the light of the findings of Thurston \& Bett (1995), a juvenile specimen of $4 \mathrm{~mm}$ is most unexpected. Allowing for the smaller size of individuals in the Arctic populations, the Thurston \& Bett (1995) data suggest a minimum hatchling size of 7 to $8 \mathrm{~mm}$. Specimens of $4 \mathrm{~mm}$ suggest that the Arctic population differs significantly from those in other oceans, and adds weight to the probability that speciation of E. gryllus in the Arctic is incipient (see Thurston et al. 2002).

Ingram \& Hessler (1983) found a size range of 3 to $12 \mathrm{~mm}$ for Orchomene gerulicorbis. The absence of small $(<7 \mathrm{~mm})$ Tmetonyx norbiensis individuals in our catches contrasts with previous findings. The absence of smaller T. norbiensis may indicate that the population is not of local origin, but results from an active immigration of older amphipods that hatched over adjacent depths. Alternative explanations might include an ontogenetic diet change-Tmetonyx species are adventitious necrophages at most-or seasonality of breeding, or a combination.

\section{CONCLUSIONS}

Scavenger aggregation dynamics and behaviour in connection with carcasses in the Arctic Ocean differed from observations reported for other deep-sea areas, with regards to the species attracted, their succession, their abundances and lengths. Scavengers are attracted and their abundances seem to be directly linked to the frequency of food falls in the area. Mobile deep-sea scavengers, such as the cosmopolitan amphipod Eurythenes gryllus, must be regarded as an important component of the deep-sea food web, considering their abundance and their role in the consumption, conversion and distribution of organic matter at the benthic-pelagic interface.

Further experiments in the Arctic Ocean are needed to determine if the findings of this study hold true for other areas and other seasons in this specific region, whether the same scavenger community is attracted, and if we can differentiate scavenger aggregations into the 2 proposed categories.

Acknowledgements. The authors are grateful to many colleagues who helped on board, and especially to the officers and crew of RV 'Polarstern' for their cooperation. For their help in the laboratory and on board we thank especially B. Wend and J. Wegner. Taxonomic identification of Tmetonyx norbiensis was kindly carried out by C. De Broyer. The manuscript was greatly improved by the constructive comments of 4 anonymous reviewers.

\section{LITERATURE CITED}

Arntz WE, Brey T, Gallardo VA (1994) Antarctic zoobenthos. Oceanogr Mar Biol Annu Rev 32:241-304

Baldwin RJ, Smith KL (1987) Temporal variation in the catch rate, length, color and sex of the necrophagous amphipod, Eurythenes gryllus, from the central and eastern North Pacific. Deep-Sea Res 34:425-439

Bregazzi PK (1973) Locomotor activity rhythms in Tryphosella kergueleni (Miers) and Cheirimedon femoratus (Pfeffer) (Crustacea; Amphipoda). Br Antarct Surv Bull 33-34: $17-32$

Britton JC, Morton B (1994) Marine carrion and scavengers. Oceanogr Mar Biol Annu Rev 32:369-434

Bowman TE, Manning RB (1972) Two Arctic bathyal crustaceans: the shrimp Bythocaris cryonesus new species, and the amphipod Eurythenes gryllus, with in situ photographs from Iceland T-3. Crustaceana 23:187-201

Charmasson SS, Calmet DP (1987) Distribution of scavenging Lysianassidae amphipods Eurythenes gryllus in the northeast Atlantic: comparison with studies held in the Pacific. Deep-Sea Res 34:1509-1523 
Charmasson SS, Calmet DP (1990) Scavenging amphipods Eurythenes gryllus from the north-east Atlantic and radioactive waste disposal. In: Baumgarten DJ, Duedall IW (eds) Oceanic processes in marine pollution. 6. Physical and chemical processes: transport and transformation. RE Krieger Publishing Company, Malabar, FL, p 227-233

Christiansen B (1996) Bait-attending amphipods in the deep sea: a comparison of three localities in the north-eastern Atlantic. J Mar Biol Assoc UK 76:345-360

Christiansen B, Pfannkuche O, Thiel H (1990) Vertical distribution and population structure of the necrophagous amphipod Eurythenes gryllus in the West European Basin. Mar Ecol Prog Ser 66:35-45

Dahl E (1979) Deep-sea carrion feeding amphipods: evolutionary patterns in niche adaptation. Oikos 33:167-175

Dayton PK, Hessler RR (1972) Role of biological disturbance in maintaining diversity in the deep sea. Deep-Sea Res 19: 199-208

De Broyer C, Jazdzewski K (1993) Biodiversity of the Southern Ocean: towards a new synthesis for the Amphipoda (Crustacea). Boll Mus Civ Stor Nat Verona 20:547-568

De Broyer C, Thurston MH (1987) New Atlantic material and redescription of the type specimens of the giant abyssal amphipod Alicella gigantea Chevreux (Crustacea). Zoolog Scripta 16:335-350

Fahrbach E (ed) (2002) The expedition ARKTIS XVII/1 of the research vessel 'Polarstern' in 2001. Reports on Polar and Marine Research, Alfred Wegener Institute for Polar and Marine Research, Bremerhaven, 433:1-43

Gooday AJ, Turley CM (1990) Responses by benthic organisms to inputs of organic material to the ocean floor: a review. Philos Trans R Soc Lond A 331:119-138

Gradinger R (1998) Life at the underside of Arctic sea-ice: biological interactions between the ice cover and the pelagic realm. Mem Soc Fauna Flora Fenn 74:53-60

Hargrave BT (1985) Feeding rates of abyssal scavenging amphipods (Eurythenes gryllus) determined in situ by time-lapse photography. Deep-Sea Res 32:443-450

Hargrave BT, Prouse NJ, Phillips GA, Cranford PJ (1994) Meal size and sustenance time in the deep-sea amphipod Eurythenes gryllus collected from the Arctic Ocean. DeepSea Res 41:1489-1508

Hessler RR, Ingram CL, Yayanos AA, Burnett BR (1978) Scavenging amphipods from the floor of the Philippine Trench. Deep-Sea Res 25:1029-1047

Ingram CI, Hessler RR (1983) Distribution and behaviour of scavenging amphipods from the central North Pacific. Deep-Sea Res 30:683-706

Ingram CI, Hessler RR (1987) Population biology of the deepsea amphipod Eurythenes gryllus: inferences from instar analyses. Deep-Sea Res 34:1889-1910

Jannasch HW (1978) Experiments in deep sea microbiology. Oceanus 21:50-57

Janssen F, Treude T, Witte U (2000) Scavenger assemblages under differing trophic conditions: a case study in the deep Arabian Sea. Deep-Sea Res II 47:2999-3026

Jones EG, Collins MA, Begley PM, Addison S, Priede IG (1998) The fate of cetacean carcasses in the deep-sea: observations on consumption rates and succession of scavenging species in the abyssal north-east Atlantic Ocean. Proc R Soc Lond B 265:1119-1127

Klages M, Vopel K, Bluhm H, Brey T, Soltwedel T, Arntz WE (2001) Deep-sea food falls: first observation of a natural event in the Arctic Ocean. Polar Biol 24:292-295

Klages M, Muyakshin S, Soltwedel T, Arntz WE (2002) Mechanoreception, a possible mechanism for food fall detection in deep-sea scavengers. Deep-Sea Res 49:143-155
Krause G, Schauer U (2001) The expedition ARKTIS XVI/2 of the research vessel 'Polarstern' in 2000. Cruise report. Reports on Polar and Marine Research, Alfred Wegener Institute for Polar and Marine Research, Bremerhaven, 389

Lampitt RS, Merrett NR, Thurston MH (1983) Inter-relations of necrophagous amphipods, a fish predator, and tidal currents in the deep sea. Mar Biol 74:73-78

Laver MB, Olsson MS, Edelman JL, Smith KL (1985) Swimming rates of scavenging deep-sea amphipods recorded with a free-vehicle video camera. Deep-Sea Res 32: 1135-1142

Legezynska J, Weslawski JM, Presler P (2000) Benthic scavengers collected by baited traps in the high Arctic. Polar Biol 23:539-544

Manley TO (1995) Branching of Atlantic water within the Greenland-Spitsbergen Passage: an estimate of recirculation. J Geophys Res 100:20627-20634

Naganuma T, Wada H, Fujioka K (1996) Biological community and sediment fatty acids associated with the deep-sea whale skeleton at Torishima seamount. J Oceanogr 52: $1-15$

Pfannkuche O, Boetius A, Lochte K, Lundgreen U, Thiel H (1999) Responses of deep-sea benthos to sedimentation patterns in the North-East Atlantic in 1992. Deep-Sea Res 46:573-596

Poltermann M (2001) Arctic sea ice as feeding ground for amphipods food sources and strategies. Polar Biol 24: 89-96

Premke K, Muyakshin S, Klages M, Wegner J (2003) Evidence for long-range chemoreceptive tracking of food odour in deep-sea scavengers by scanning sonar data. J Exp Mar Biol Ecol 285/286:283-294

Priede IG, Merrett NR (1996) Estimation of abundance of abyssal demersal fishes; a comparison of data from trawls and baited cameras. J Fish Biol 49(Suppl A):207-216

Priede IG, Merrett NR (1998) The relationship between numbers of fish attracted to baited cameras and population density: studies on demersal grenadiers Coryphaenoides (Nematonurus) armatus in the abyssal NE Atlantic Ocean. Fish Res 36:133-137

Priede IG, Smith KL, Armstrong JD (1990) Foraging behaviour of abyssal grenadier fish: inferences from acoustic tagging and tracking in the North Pacific Ocean. DeepSea Res 37:81-101

Priede IG, Bagley PM, Armstrong JD, Smith KL Jr, Merrett NR (1991) Direct measurement of active dispersal of foodfalls by deep-sea demersal fishes. Nature 351:647-649

Rakusa-Suszczewski S (1982) The biology and metabolism of Orchomene plebs (Hurley, 1965) (Amphipoda: Gammaridea) from McMurdo Sound, Ross Sea, Antarctic. Polar Biol 1:47-54

Rice AL, Thurston MH, Bett BJ (1994) The IOSDL DEEPSEAS programme: introduction and photographic evidence for the presence and absence of a seasonal input of phytodetritus at contrasting abyssal sites in the northeastern Atlantic. Deep-Sea Res 41:1305-1320

Rowe GT, Sibuet M, Vangriesheim A (1986) Domains of occupation of abyssal scavengers inferred from baited cameras and traps on the Demerara Abyssal Plain. Deep-Sea Res 33:501-522

Rudels B, Meyer R, Fahrbach E, Ivanov V and 5 others (2000) Water mass distribution in Fram Strait and over the Yermak Plateau in summer 1997. Ann Geophys 18:687-705

Sainte-Marie B (1984) Morphological adaptations for carrion feeding in four species of littoral or circa littoral lysianassid amphipods. Can J Zool 62:1668-1674 
Sainte-Marie B (1992) Foraging of scavenging deep-sea lysianassoid amphipods. In: Rowe GT, Pariente V (eds) Deep-sea food chains and the global carbon cycle. Kluwer Academic Publishers, Dordrecht, p 105-124

Sainte-Marie B, Hargrave BT (1987) Estimation of scavenger abundance and distance of attraction to bait. Mar Biol 94: 431-443

Sainte-Marie B, Percy JA, Shea JR (1989) A comparison of meal size and feeding rate of the lysianassid amphipods Anonyx nugax, Onisimus (=Pseudalibrotus) litoralis and Orchomenella pinguis. Mar Biol 102:361-368

Sanders HL (1968) Marine benthic diversity: a comparative study. Am Nat 102:243-282

Schauer U, Fahrbach E, Osterhus Rohardt G (2004) Arctic warming through Fram Strait-Oceanic heat flow from three years of current measurements. J Geophys Res 109:C02015, doi:10.1029/2003 JC002008

Smith CR (1985) Food for the deep sea: utilization, dispersal, and flux of nekton falls at the Santa Catalina Basin floor. Deep-Sea Res 32:417-442

Smith CR, Kukert H, Wheatcroft RA, Jumars PA, Deming JW (1989) Vent fauna on whale remains. Nature 341: 27-28

Smith CR, Maybaum HJ, Baco AR, Pope RH, Carpenter SD, Yager PL, Macko SA, Deming JW (1998) Sediment community structure around a whale skeleton in the deep Northeast Pacific: macrofaunal, microbial and bioturbation effects. Deep-Sea Res II 45:335-364

Smith KL, Baldwin RJ (1982) Scavenging deep-sea amphipods: effects of food odor on oxygen consumption and a proposed metabolic strategy. Mar Biol 68:287-298

Smith KL, Baldwin RJ (1984) Vertical distribution of the necrophagous amphipod, Eurythenes gryllus, in the North Pacific: spatial and temporal variation. Deep-Sea Res 31: 1179-1196

Soltwedel T, von Juterzenka K, Premke K, Klages M (2003) What a lucky shot! Photographic evidence for a medium-

Editorial responsibility: Otto Kinne (Editor-in-Chief), Oldendorf/Luhe, Germany sized natural food-fall at the deep seafloor. Oceanol Acta 26:623-628

Somero GN, Siebenaller JF, Hochacka PW (1983) Biochemical and physiological adaptations of deep-sea animals. In: Rowe GT (ed) The sea, Vol 8. John Wiley \& Sons, New York, p 331-370

Svedrup HU, Johnson MW, Fleming RH (1942) The oceans. Prentice-Hall, Engelwood Cliffs, NJ

Thiel H, Pfannkuche O, Schriever G, Lochte K and 6 others (1989) Phytodetritus on the deep-sea floor in a central oceanic region of the Northeast Atlantic. Biol Oceanogr 6: 203-239

Thurston MH (1979) Scavenging abyssal amphipods from the north-east Atlantic Ocean. Mar Biol 51:55-68

Thurston MH (1990) Abyssal necrophagous amphipods (Crustacea: Amphipoda) in the northeast and tropical Atlantic Ocean. Prog Oceanogr 24:257-274

Thurston MH, Bett BJ (1995) Hatchling size and aspects of biology in the deep-sea amphipod genus Eurythenes (Crustacea: Amphipoda). Int Rev Gesamten Hydrobiol 8:201-216

Thurston MH, Bett BJ, Rice AL (1995) Abyssal megafaunal necrophages: latitudinal differences in the eastern North Atlantic Ocean. Int Rev Gesamten Hydrobiol 8:267-286

Thurston MH, Petrillo M, Della Croce N (2002) Population structure of the necrophagous amphipod Eurythenes gryllus (Amphipoda: Gammaridea) from the Atacama Trench (south-east Pacific Ocean). J Mar Biol Assoc UK 82:205-211

Vinogradov ME, Vinogradov GM (1991) Scavenging amphipods from a bottom-trap set on the Nasca underwater mountain ridge. Zool Zh 70(6):32-38 (in Russian)

Walker AO (1907) Crustacea. III. Amphipoda. Natl Antarc Exped 1901-1904 Nat Hist 3:1-39

Witte U (1999) Consumption of large carcasses by scavenger assemblages in the deep Arabian Sea: observation by baited camera. Mar Ecol Prog Ser 183:139-174

Submitted: August 11, 2003; Accepted: March 22, 2006

Proofs received from author(s): September 11, 2006 